\title{
Overweight Exceeds Underweight among Women in Kerala: An Analysis of Trends and Determinants
}

\author{
P. Ramesh ${ }^{1}$ and S. Jareena ${ }^{2}$ \\ ${ }^{1}$ Population Research Centre, Gokhale Institute of Politics and Economics, BMCC Road, Pune, \\ Maharashtra, India \\ E-mail:ramesh.poluru@gmail.com,avkavya@rediffmail.com \\ ${ }^{2}$ International Institute for Population Sciences, Govadhi Station Road, Deonar, Mumbai, \\ Maharashtra, India \\ E-mail: jareenas@gmail.com
}

KEYWORDS Nutrition Transition. Body Mass Index. Logistic Regression Analysis

\begin{abstract}
While under-nutrition (underweight and stunting) is still prevalent in India, the rates of overweight and obesity are steadily increasing, especially among adults. In Kerala, the rates of overweight and obese exceeded underweight. This paper examines the trends in the shift from underweight to overweight and identify the major determinants of the co-existence of 'double burden' of malnutrition among women of reproductive age 15-49 years using the data from National Nutrition Monitoring Bureau (NNMB) diet and nutrition surveys and the second National Family Health Survey (NFHS-2). Results of the multivariate logistic regression analyses on NFHS-2 data show that household standard of living and age are significantly associated with both underweight and overweight or obesity. On the other hand, work status, residence and caste are not significant on women's nutritional status. Among others, Muslim and Christian women, women who watch television more than once a week and women who reported eating fruits daily and consume chicken or meat or fish are more likely to be overweight or obese than their counterparts. The risk of chronic energy deficiency or underweight is significantly higher among never married women and lower among literate women. In summary, both underweight and overweight or obesity are equally present in Kerala and there is a need for public health programs that are able to address both simultaneously.
\end{abstract}

\section{INTRODUCTION}

Epidemiological, demographic and nutritional transitions are taking place in many developing countries. Although under-nutrition (underweight and stunting) is still prevalent in most of the developing countries, the rates of overweight or obesity are steadily increasing, especially among adults. Hence, the countries in transition face today new public health problems, while they are yet to eradicate completely the nutritional deficiencies. Overweight or obesity is a risk factor for a number of chronic non-communicable diseases, such as diabetes, hypertension, asthma, cardiovascular disease, some cancers, gall bladder disease and osteoarthritis - all of which are on the rise in developing countries, particularly among the middle-class, urban populations (Gopalan 1998; Popkin et al. 2001). On the other hand, the chronic energy deficiency/ underweight is associated with impaired physical capacity, reduced economic productivity, increased mortality and poorer reproductive outcomes (National Institute of Nutrition 1991; World Health Organization 1995). Based on the analysis of anhropometric measurements for women age $20-49$ in 36 developing countries, Mentez et al. (2005) observed that the proportion of overweight exceeded the proportion of underweight in a majority of the counties in both urban and rural areas. These results are contrary to the general belief that in developing counties overweight is less prevalent than underweight and that it is primarily concentrated in urban, higher socioeconomic status households.

For social and biological reasons, women of the reproductive age are amongst the most vulnerable to malnutrition. Several reviews have also emphasized the vulnerability of women throughout their life cycle (Merchant and Kurtz 1993; Tinker 1995). In India, which is typically known for large incidence of under-nutrition, significant proportions of overweight or obese women now coexist with the undernourished (IIPS and ORC Macro 2000,2006) and there is some evidence of even emerging nutrition transition also (Griffiths and Bentley 2001; Shetty 2002). Table 1 shows the percentage of ever-married women age 15-49 according to level of body mass index by state and three metro cities. More than one-third of women in India (36 percent) have a chronic energy deficiency/underweight (BMI, 
$<18.5 \mathrm{~kg} / \mathrm{m}^{2}$ ) and at state level, the disparities are quite widespread, ranging from 11 to 48 percent. Prevalence was $\geq 20$ percent in $19(70 \%)$ of the 27 states and $\geq 30$ percent in 11 states ( $41 \%$ ) of India. Although under-nutrition is still prevalent, on the other hand, there is an alarming prevalence of overweight and obesity among Indian women of childbearing age. Eleven percent women are overweight or obese (BMI, $\geq 25.0 \mathrm{~kg} / \mathrm{m}^{2}$ ). According to the preliminary findings of the

Table 1: Percentage of ever-married women age 15-49 years with specific levels of Body Mass Index $\left(\mathrm{BMI}^{1}\right)$, by state and metropolitan areas, India, 1998-99

\begin{tabular}{|c|c|c|c|c|c|}
\hline $\begin{array}{l}\text { Level of } B M I, \mathrm{~kg} / \mathrm{m}^{2} \\
\text { (1) }\end{array}$ & $\begin{array}{c}B M I,<18.5 \\
(2)\end{array}$ & $\begin{array}{l}B M I, 25.0-29.9 \\
(3)\end{array}$ & $\begin{array}{c}B M I, \geq 30.0 \\
(4)\end{array}$ & $B M I, \geq 25.0$ & $\begin{array}{c}B M I, \geq 23.0 \\
(6)\end{array}$ \\
\hline \multicolumn{6}{|l|}{ North } \\
\hline Delhi & 12.1 & 24.7 & 9.3 & 34.0 & 49.9 \\
\hline Haryana & 26.1 & 12.8 & 3.9 & 16.7 & 26.4 \\
\hline Himachal Pradesh & 29.9 & 10.9 & 2.4 & 13.3 & 22.9 \\
\hline Jammu and Kashmir & 26.6 & 10.7 & 3.0 & 13.7 & 24.3 \\
\hline Punjab & 17.0 & 21.4 & 9.2 & 30.6 & 43.9 \\
\hline \multicolumn{6}{|l|}{ Central } \\
\hline Madhya Pradesh & 38.6 & 4.9 & 1.2 & 6.1 & 12.0 \\
\hline Uttar Pradesh & 36.2 & 5.9 & 1.6 & 7.5 & 14.6 \\
\hline \multicolumn{6}{|l|}{ East } \\
\hline Bihar & 39.7 & 3.2 & $(0.5)$ & 3.7 & 8.5 \\
\hline Orissa & 48.4 & 3.8 & $(0.6)$ & 4.4 & 9.1 \\
\hline West Bengal & 44.4 & 7.3 & 1.3 & 8.6 & 15.3 \\
\hline \multicolumn{6}{|l|}{ North-east } \\
\hline Arunachal Pradesh & 11.1 & $(4.5)$ & $(0.6)$ & $(5.2)$ & 12.0 \\
\hline Assam & 27.1 & 3.5 & $(0.7)$ & 4.3 & 11.2 \\
\hline Manipur & 19.3 & 9.7 & $(1.1)$ & 10.8 & 22.5 \\
\hline Meghalaya & 25.8 & $(4.7)$ & $(1.2)$ & $(5.9)$ & 13.7 \\
\hline Mizoram & 22.8 & $(4.9)$ & $(0.6)$ & $(5.3)$ & 12.9 \\
\hline Nagaland & 18.7 & 7.8 & $(0.8)$ & 8.6 & 20.5 \\
\hline Sikkim & 11.3 & 13.1 & $(2.5)$ & 15.6 & 31.0 \\
\hline Tripura & 35.4 & 6.8 & $(1.7)$ & 8.5 & 18.4 \\
\hline \multicolumn{6}{|l|}{ West } \\
\hline Goa & 27.5 & 16.8 & 4.5 & 21.3 & 34.4 \\
\hline Gujarat & 37.6 & 11.4 & 4.4 & 15.9 & 25.5 \\
\hline Maharashtra & 40.2 & 9.0 & 2.9 & 11.9 & 20.1 \\
\hline Rajasthan & 36.6 & 5.5 & 1.7 & 7.2 & 13.5 \\
\hline \multicolumn{6}{|l|}{ South } \\
\hline Andhra Pradesh & 37.8 & 9.8 & 2.3 & 12.1 & 20.6 \\
\hline Karnataka & 39.4 & 10.8 & 2.9 & 13.7 & 21.7 \\
\hline Kerala & 18.9 & 17.0 & 3.9 & 20.9 & 35.6 \\
\hline Tamil Nadu & 29.3 & 12.1 & 2.7 & 14.7 & 25.5 \\
\hline \multicolumn{6}{|l|}{ Metros } \\
\hline Chennai & 16.0 & 20.5 & $(5.7)$ & 26.2 & 41.8 \\
\hline Kolkata & 18.2 & 22.4 & $(6.5)$ & 29.0 & 43.0 \\
\hline Mumbai & 18.0 & 23.7 & 8.5 & 32.1 & 46.8 \\
\hline India & 36.2 & 8.4 & 2.3 & 10.6 & 18.5 \\
\hline
\end{tabular}

Notes: 1. The body mass index (BMI) is the ratio of weight in kilograms to the square of the height in metres $\left(\mathrm{kg} / \mathrm{m}^{2}\right)$.

2. According to BMI status, women are categorized in to six groups: (Col. 2): Underweight (BMI, $<18.50 \mathrm{~kg} /$ $\mathrm{m}^{2}$ ); (Col. 3): Overweight (BMI, 25.0-29.9 kg/m²); (Col. 4): Obese (BMI, $\geq 30 \mathrm{~kg} / \mathrm{m}^{2}$ ); Col. 5: Total Overweight or obese (BMI, $\geq 25.0 \mathrm{~kg} / \mathrm{m}^{2}$ ); Col. 6: WHO proposed Overweight and obese (BMI, $\left.\geq 23.0\right)$ for Asian population (Choo, 2002).

3. For the 15-17 year-old adolescent females in the sample, the cut-off points recommended by Cole et al. (2000) for adolescent overweight or obesity were used (For details, see Ramesh 2006).

4. Table excludes women who are pregnant and women with a birth in the preceding two months.

5. State-level sample weights incorporate for State results, and national-level sample weights incorporate for India results.

6. All-India estimates in these tables will differ slightly from similar estimates in the NFHS-2 national report (IIPS and ORC Macro 2000:246). Because, Tripura state was not included in the tables for the NFHS-2, India report due to late start of fieldwork (survey) in Tripura.

7. ( ) Percentage based on fewer than 50 un-weighted cases.

Source: computed from NFHS-2, 1998-99 data files of India 
subsequent survey, the NFHS-3 carried out in 2005-06, about one-third of married women are too thin and 15 per cent are overweight or obese. The proportion of overweight or obese is exceeded the proportion of underweight in Delhi, Punjab, Kerala, Jammu Kashmir, Goa, Tamil Nadu, Sikkim and Manipur states (IIPS and ORC Macro 2006) and in all the three metro cities (Table 1). In all, about half of married women are either underweight or overweight. This pattern reveals that a significant proportion of overweight or obese women coexisting with high rates of underweight women.

Though malnutrition among women has long been recognized as a serious problem in India, most of the research on determinants of malnutrition among women has concentrated either on underweight or overweight. Very little has been done on the emerging dual burden of both forms of malnutrition, particularly among women (Griffiths and Bentley 2001; Shukla et al. 2002; Roy et al. 2004). Many factors have been associated with both forms of malnutrition of women in the literature. These include the socioeconomic (e.g., educational background, occupation and household income); cultural (e.g., religion and caste); demographic (e.g., age and marital status) and dietary characteristics (Singh et al. 1999; Griffiths and Bentley 2001; Shukla et al. 2002; Roy et al. 2004). This paper therefore, sheds light on the emerging 'double burden' of malnutrition among women and its linkages with socioeconomic, demographic and other characteristics in the state of Kerala, where the proportion of overweight or obese is exceeded the proportion of underweight. Specifically, this paper will attempt first, to explore the trends in the nutrient intakes and shift from underweight to overweight among rural women during the last three decades and secondly, it analyses the differentials and identify the distinct factors that may influence malnutrition among women. In this paper, malnutrition refers to problems of both under-nutrition and over-nutrition. Data from the National Nutrition Monitoring Bureau (NNMB) diet and nutrition surveys are used for understanding of secular trends of malnutrition and the second National Family Health Survey (NFHS-2), 1998-99 are used for examining the prevalence and determinants of malnutrition among ever-married women of reproductive age 15-49. The NFHS-3 unit level data are yet to become available for the state of Kerala and India and the preliminary findings of the NFHS-3 also reports higher prevalence of malnutrition in the state. Therefore, for understanding of the factors associated with both forms of malnutrition (underweight and overweight or obese), we believe that analysis based on the NFHS-2 will still be useful programmatically.

\section{The Setting}

Kerala is situated on the southwest coast of India with the Western Ghat Mountains forming its eastern border. According to the 2001 Census, Kerala had a population of 31.8 million, accounts for 3.1 per cent of India's population and for 1.2 per cent of its land area (India, Registrar General, 2004). Various demographic and socioeconomic features of Kerala and India are outlined in Table 2. Kerala has achieved remarkable progress in human development, as reflected in the high levels of education and health of its population. Kerala's demographic experience has attracted wide attention both at the national and the international levels. Crude death rate, infant mortality rate and life expectancy at birth are comparable even to those in the developed countries. As of 2002, the birth rate in Kerala was estimated as 16.9 births (per 1000 population), as against 25.0 for all-India. The crude death rate was 6.4 deaths (per 1000 population), compared to the national average of 8.1 (India, Registrar General 2004). Thus, Kerala has apparently entered the third or final phase of the demographic transition characterized by low death rate and declining birth rate leading to a slow down in the growth rate of population. Kerala has made significant advances not only in demographic transition but also in epidemiological, and health care transitions (for more discussion on the epidemiological and health care transitions in Kerala, see Panikar and Soman 1981; Panikar 1999).

\section{Trends of Food Consumption and Malnutrition in Rural Areas of Kerala}

Since the formation of the state in 1956 to 1970, the nutrient intakes (both energy and proteins) had been consistently lower than the recommended dietary allowances (Panikar and Soman 1981: 24). However, the trends in the intake of both energy and proteins observed from the NNMB data reflect almost steady increase over the last two decades in the rural areas. Between 
Table 2: Selected socioeconomic and demographic indicators, Kerala and India

\begin{tabular}{|c|c|c|}
\hline Indicators & Kerala & India \\
\hline Population, 2001 (in millions) & 31.8 & 1028.6 \\
\hline Population decadal growth rate (per cent), 1991-2001 & 9.42 & 21.35 \\
\hline Population density (persons $/ \mathrm{Km}^{2}$ ), 2001 & 819 & 324 \\
\hline Per cent urban, 2001 & 26.0 & 27.8 \\
\hline Crude death rate, 2002 & 6.4 & 8.1 \\
\hline Crude birth rate, 2002 & 16.9 & 25.0 \\
\hline Natural growth rate, 2002 & 10.5 & 16.9 \\
\hline Infant mortality rate, 2002 & 10 & 63 \\
\hline Total fertility rate (NFHS-2, 1996-98) & 1.96 & 2.85 \\
\hline Life expectancy at birth (in years) - Males, 1993-97 & 70.4 & 60.4 \\
\hline Life expectancy at birth (in years) - Females, 1993-97 & 75.9 & 61.8 \\
\hline Infant mortality rate (NFHS-2, 1999) & 20.9 & 67.6 \\
\hline Under-five mortality rate (NFHS-2, 1999) & 26.0 & 94.9 \\
\hline Incidence of low birth $(<2.5 \mathrm{~kg})$ Weight (NFHS-2, 1998-99) & 15.1 & 5.7 \\
\hline Per cent of small size baby's at birth (NFHS-2, 1998-99) & 24.9 & 24.4 \\
\hline Per cent of miscarriages (NFHS-2, 1998-99) & 8.8 & 8.1 \\
\hline Prevalence of Asthma (No. of persons per $1,00,000$ population, NFHS-2) & 4,806 & 2468 \\
\hline Per cent literate (females age $7+$ ), 2001 & 87.7 & 53.6 \\
\hline Work participation rate, 2001 & 32.3 & 39.1 \\
\hline Percentage of population below poverty line, 1999-2000 & 13 & 26 \\
\hline Per capita net state domestic product (at 1993-94 prices, Rs.) 1998-99 & 9,542 & 9,647 \\
\hline Per capita income at constant $1993-94$ prices (Rs) $2000-01$ & 10,627 & 10,306 \\
\hline Per capita income at current prices (Rs.), 2000-01 & 19,463 & 16,707 \\
\hline
\end{tabular}

Source: India, Registrar General (2004); IIPS and ORC Macro (2000; 2001); CSO (1999).

1975-79 and 1996-97, the average intake of energy by rural households increased from 1,978 to 2,106 Kcal, but below the recommended dietary allowances (RDA) of 2,425 Kcal. The average intake of proteins in rural households increased from $46 \mathrm{gm}$ to $56 \mathrm{gm}$, as against the RDA of $60 \mathrm{gm}$. During the same periods (1975-79 and 1996-97), the proportion of households with proteinadequacy and calorie-adequacy showed an increase of 28 per cent and 13 per cent, respectively. Thus, the proportion of households with adequate protein and energy intake registered a moderate increase between the late 1970s and the 1990s (Table 3).

On the other hand, a decreasing trend in the prevalence of underweight and an increasing trend in the proportions of overweight or obese were also observed over the last two decades. Between 1975-79 and 2000-2001, the extent of chronic energy deficiency (CED)/ underweight declined from 47 per cent in $1975-79$ to 25 per cent in 1996-97 (according to NNMB repeat surveys) and from 28 per cent in 1991-92 to 19 per cent in 2000-01 (according to NNMB-NSS sample design). During the same period, a consistent increasing trend was observed in the proportions of overweight or obese among rural women, from 2 per cent to 12 per cent and then from 16 to 24 per cent, respectively. The NFHS-2 and 3 also show that the prevalence of underweight continues to decline and the overweight and obese continues to increase in the state. As per NFHS-2, about one-fifth of evermarried women of age 15-49 in rural areas are underweight and overweight or obese (Table 4). According to the latest NFHS-3 estimates, the prevalence of underweight and overweight or obese is 13 and 34 per cent, respectively, that is, about half of (47 percent) women are either underweight or overweight/obese. In rural areas

Table 3: Trends in average consumption of Nutrients (CU per Day) and Proportion of households with Protein-energy adequacy status in rural areas of Kerala, National Nutrition Monitoring Bureau (NNMB) estimates

\begin{tabular}{|c|c|c|c|c|}
\hline Consumption of nutrients & $1975-79$ & $1988-90$ & $1996-97$ & $R D A$ \\
\hline Energy (Kcal per consumption unit) & 1978 & 2140 & 2106 & 2425 \\
\hline Protein ( $g$ per consumption unit) & 46.4 & 52.9 & 56.4 & 60.0 \\
\hline Protein adequate (per cent) & 55.7 & 71.5 & 83.5 & - \\
\hline Calorie adequate (per cent) & 36.0 & 39.7 & 49.3 & - \\
\hline
\end{tabular}

Note: RDA: Recommended Dietary Allowance by ICMR (1990)

Source: NNMB (1991: 50 and 52; 1999:8). 
Table 4: Percentage distribution of adult women in rural areas of Kerala by Body Mass Index (BMI): NNMB and NFHS-2 estimates

\begin{tabular}{llccccc}
\hline Nutritional grade / Level of BMI $\left(\mathrm{Kg} / \mathrm{m}^{2}\right)$ & $1975-79 *$ & $1991-92 *$ & $1996-97 @$ & $2000-01 @ 1998-99 \$$ \\
\hline Underweight/Thinness & & & & & & \\
$\quad$ Grade-3 (Severe) & $<16.0$ & 10.5 & 6.1 & 5.1 & 3.0 & 3.0 \\
$\quad$ Grade-2 (Moderate) & $16.0-16.9$ & 10.5 & 6.5 & 6.4 & 4.7 & 4.0 \\
$\quad$ Grade-1 (Mild) & $17.0-18.49$ & 26.2 & 15.2 & 13.1 & 11.0 & 13.2 \\
Total underweight & $<18.5$ & 47.2 & 27.8 & 24.8 & 18.7 & 20.2 \\
Normal weight & $18.5-24.99$ & 50.5 & 60.0 & 59.7 & 57.7 & 60.3 \\
Overweight/obese & $\mathrm{e} " 25.0$ & 2.3 & 12.2 & 15.8 & 23.6 & 19.5 \\
\hline Total N & & 1062 & 3480 & 1913 & 1986 \\
\hline
\end{tabular}

Note: * - NNMB Repeat Surveys; @ - NNMB-NSS Sample design surveys; \$ - NFHS-2, 1998-99

Source: NNMB (1991, 1993, 1999 and 2002); NFHS-2, data files of Kerala.

also, about one-third (31 per cent) of ever-married women are overweight or obese and 14 per cent of women are underweight.

\section{MATERIALS AND METHODS}

The anthropometric data used for analysis in this paper were derived from the second National Family Health Survey, 1998-99 (NFHS-2) for the state of Kerala. The objective of the survey were to provide state-level estimates on fertility, family planning practices, infant and child mortality, reproductive and child health, quality of health and family welfare services. Data were collected from 2,884 ever-married women of age group 1549 in 2,834 households. In addition, the survey also collected measures of height and weight from 2,770 ever-married women (96 per cent of those ever-married women interviewed). The details of the study design as well as sampling frame and sample implementation are provided in the state NFHS-2 report (IIPS and ORC Macro 2001). In NFHS-2, all ever-married women aged 15-49 years were weighed using a solar-powered scale with an accuracy of $\pm 100 \mathrm{~g}$. Their height was measured using an adjustable wooden measuring board, specifically designed to provide accurate measurements (to the nearest $0.1 \mathrm{~cm}$ ) in a developing country field situation. The weight and height data were used to calculate the Body Mass Index (BMI). The BMI is defined as weight in kilograms divided by the height in meters squared $\left(\mathrm{kg} / \mathrm{m}^{2}\right)$. Based on the WHO (1995) recommendations, the BMI variable was categorized into three categories for the analysis, indicating underweight (BMI $<18.50$ $\mathrm{kg} / \mathrm{m}^{2}$ ), normal weight (BMI $18.5-24.9 \mathrm{~kg} / \mathrm{m}^{2}$ ) and overweight or obese $\left(\mathrm{BMI} \geq 25.00 \mathrm{~kg} / \mathrm{m}^{2}\right)$. For the 15-17 years old females in the NFHS-2 sample, the cut-off points recommended by Cole et al. (2000) for adolescent obesity and overweight were used because the BMI values change substantially with age in adolescents. The WHO (1995) overweight grade-III definition of BMI >40 was not used because of only five women in the sample. Among 2770 ever-married women from whom anthropometric data were collected, measurements of height and weight for six women were incomplete or affected by measurement errors. Women who were pregnant at the time of the survey are 145 and 31 women gave birth during the two months preceding the survey. These 181 women $(6+145+31)$ were excluded from the analysis. This is to avoid the exaggerated BMI values for the women due to their pregnancy status. Thus, 2589 ever-married women were included in the analysis, of whom, 489 were underweight, 1560 were normal weight and 540 were overweight or obese.

In analyzing the data, both bivariate and multivariate analyses were carried out. In the bivariate analysis, the chi-square test is employed to see the association between each of the independent variables and the nutritional status of women. The chi-square test in the bi-variate analysis does not consider confounding effects. Therefore, multivariate analysis is used to examine the net effect of each independent variable on malnutrition of women, while controlling for the other independent variables. As such two separate logistic (logit) regression models were used to identify and to compare the factors associated with women being underweight (BMI $\left.<18.50 \mathrm{~kg} / \mathrm{m}^{2}\right)$ in the first model $(\mathrm{n}=2,039)$ and women being overweight or obese (BMI $\geq 25.00$ $\left.\mathrm{kg} / \mathrm{m}^{2}\right)$ in the second model $(\mathrm{n}=2,112)$. In both of the models, underweight and overweight women were compared with normal weight (BMI, 18.5$24.9 \mathrm{~kg} / \mathrm{m}^{2}$ ) women. The effect of one variable on the prevalence of malnutrition is likely to be confounded with the effects of other variables. Therefore, socioeconomic, demographic and other 
sedentary lifestyle characteristics were controlled statistically. The variables included as controls are: residence, religion, caste/tribe, education, marital status and current age as the sociodemographic variables. Since, the NFHS=2 did not collect information on household income/ expenditure, energy intake/expenditure and sedentary lifestyles characteristics, with the limited information available in the data set, the following (economic and sedentary lifestyle) indicators are used as proxy variables, apart from the above socio-demographic variables. They are: household standard of living Index (as measured by the NFHS-2, IIPS and ORC Macro, 2000a: 27-29, based on the housing conditions and ownership of consumer durables, which is used as a proxy for economic status); women who consume meat/chicken/fish daily (high energy or nutrient dense diets); occupation and who watch television once a week (physical activity). Further, the NFHS-2 data also show that women who ate fruits more frequently lived in households with a higher standard of living index. This shows that these households were more likely to have the resources to buy expensive fruits, processed foods and to consume diets high in fat and sugar. Therefore, frequent consumption of fruits (women who ate fruits daily) is used as a proxy measure for other aspects of economic status not captured in the standard of living index.

\section{RESULTS}

\section{Background Characteristics of Women}

Percentage distribution of ever-married nonpregnant women of age 15-49 according to selected socioeconomic, demographic and other sedentary lifestyle characteristics, along with differentials in the prevalence of both forms of malnutrition are presented in Table 5. More than three-fourths (77 per cent) of women were from rural areas. Fifty-two per cent of the women were Hindus and 31 per cent were Muslims. Forty-three per cent of respondents belong to the other backward classes, ten per cent belong to the scheduled castes/tribes and nearly half (47 per cent) of women did not belong to any of these caste or class groups. Thirteen per cent of women were illiterates and about two-fifths (39 per cent) of women completed high school and above level of education. More than three-quarters of women (76 per cent) did not participate in work other than their regular housework during the 12 months preceding the survey. Twenty-nine per cent of women hailed from high household standard of living group and 16 per cent from low standard of living group. Nearly half of women (47 per cent) were in the age group 35-49 and more than onethird ( 37 per cent) of women were in the age group of 25-34. Ninety-three per cent of women were currently married and seven per cent were not currently married i.e., widowed, divorced, separated or abandoned women. With regard to lifestyle indicators, such as media and food habits, 63 per cent of women watched television at least once a week. More than three-fifths (62 per cent) of women consumed chicken or meat or fish daily and 83 per cent consumed these items at least once a week. In addition, 17 per cent of women consumed fruits daily and 57 per cent consumed them at least once a week (Table 5).

\section{Differentials in the Prevalence of Underweight and Overweight}

The results of the bi-variate analysis (Table 5) using the chi-square test showed a significant association between the BMI groups and each of the explanatory variables. Table 5 also show that more than one-fifths (21 per cent) of women were overweight or obese, but this percentage is considerably higher for some groups of women (33 per cent of women from high household standard of living, 30 per cent of women who consume fruits daily, 26 per cent of women of age 35-49, 25 per cent of urban women, 23 per cent of women who consume chicken/meat/fish daily, or who have completed at least high school education). On the other hand, the total prevalence of underweight/chronic energy deficiency (CED) was 19 per cent. Underweight/ chronic energy deficiency was particularly serious for women who belong to households with a low standard of living i.e., women from households with a low standard of living were more than thrice as likely to have a low BMI as women from households with a high standard of living. In addition, underweight was also pronounced among women of scheduled caste (28 per cent), illiterate women (26 per cent), younger women (25 per cent), Hindu or workingwomen (22 per cent), and rural women (20 per cent). Women who eat fruits or chicken, meat, or fish on a daily basis were less likely to have CED than the other women. Further, it has also been observed that the prevalence of 
overweight or obese exceeded underweight among women from urban areas, Muslim, Christian and 'other' caste women, well educated, non-working, women from higher standard of living group, older women, who watches television at least once in a week and who consumes fruits daily (Table 5).

\section{Determinants of Underweight and Overweight}

It was observed from the earlier bi-variate analysis that there are differentials in the prevalence of both forms of malnutrition by selected socioeconomic, demographic and other variables. However, some of these variables are

Table 5: Percentage distribution of non-pregnant women aged 15-49 years, and women classified as underweight $\left(\mathrm{BMI}^{1},<18.5 \mathrm{~kg} / \mathrm{m}^{2}\right)$, normal weight $\left(18.5-24.9 \mathrm{~kg} / \mathrm{m}^{2}\right)$ and overweight or obese $(\mathrm{BMI}, \geq 25.0$ $\mathrm{kg} / \mathrm{m}^{2}$ ), according to selected background characteristics, Kerala, NFHS-2, $1998-99$

\begin{tabular}{|c|c|c|c|c|c|c|}
\hline \multirow[t]{2}{*}{ Characteristic } & \multirow{2}{*}{$\begin{array}{l}\text { Distribution (\%) } \\
\text { of women } \\
\text { (2) }\end{array}$} & \multicolumn{3}{|c|}{ Women classified as } & \multirow{2}{*}{$\begin{array}{c}\text { Number } \\
\text { of women } \\
\text { (6) }\end{array}$} & \multirow{2}{*}{$\begin{array}{l}\chi^{2} \text { value and } \\
\text { level of } \\
\text { significance } \\
\text { (7) }\end{array}$} \\
\hline & & $\begin{array}{c}\text { Under } \\
\text { weight } \\
\text { (3) }\end{array}$ & $\begin{array}{c}\text { Normal } \\
\text { weight } \\
\text { (4) }\end{array}$ & $\begin{array}{c}\text { Over } \\
\text { weight } \\
\text { (5) }\end{array}$ & & \\
\hline Residence & & & & & & $16.35 * * *$ \\
\hline Rural & 76.8 & 20.2 & 60.2 & 19.5 & 1987 & \\
\hline Urban & 23.2 & 14.3 & 60.2 & 25.5 & 601 & \\
\hline Religion & & & & & & $36.32 * * *$ \\
\hline Hindu & 51.2 & 21.8 & 61.1 & 17.1 & 1351 & \\
\hline Muslim & 31.4 & 17.4 & 58.0 & 24.6 & 814 & \\
\hline Christian & 16.4 & 12.5 & 61.8 & 25.7 & 424 & \\
\hline Caste/Tribe & & & & & & $30.28 * * *$ \\
\hline Scheduled caste/tribe & 9.7 & 28.2 & 59.9 & 11.9 & 252 & \\
\hline Other backward class & 43.4 & 19.9 & 59.6 & 20.5 & 1125 & \\
\hline Other caste & 46.8 & 16.0 & 60.9 & 23.1 & 1212 & \\
\hline Education & & & & & & $26.31 * * *$ \\
\hline Illiterate & $13 \ldots 1$ & 26.5 & 59.9 & 13.6 & 339 & \\
\hline Literate, $<$ middle & 31.1 & 19.8 & 59.4 & 20.9 & 805 & \\
\hline Middle school & 17.1 & 17.3 & 60.9 & 21.8 & 445 & \\
\hline High school and above & 38.6 & 16.2 & 60.9 & 22.9 & 999 & \\
\hline Work status & & & & & & $12.22 * *$ \\
\hline Not-working & 76.2 & 17.8 & 60.0 & 22.2 & 1971 & \\
\hline Working & 23.8 & 22.2 & 61.2 & 16.6 & 616 & \\
\hline Standard of Living & & & & & & $165.66 * * *$ \\
\hline Low & 15.7 & 33.7 & 57.1 & 9.1 & 406 & \\
\hline Medium & 55.5 & 19.3 & 62.9 & 17.9 & 1422 & \\
\hline High & 29.4 & 10.3 & 57.0 & 32.8 & 760 & \\
\hline Current Age & & & & & & $76.09 * * *$ \\
\hline $15-24$ & 13.5 & 25.4 & 66.6 & 8.0 & 350 & \\
\hline $25-34$ & 36.8 & 22.4 & 59.0 & 18.7 & 953 & \\
\hline $35-49$ & 49.7 & 14.5 & 59.5 & 26.0 & 1285 & \\
\hline Marital Status & & & & & & $10.29 * *$ \\
\hline Currently married & 92.6 & 18.2 & 60.5 & 21.3 & 2397 & \\
\hline Not currently married & 7.4 & 26.9 & 57.5 & 15.5 & 193 & \\
\hline Watches TV Every Week & & & & & & $58.22 * * *$ \\
\hline No & 37.2 & 25.5 & 59.2 & 15.3 & 961 & \\
\hline Yes & 62.8 & 15.0 & 60.8 & 24.2 & 1627 & \\
\hline Fruits Daily & & & & & & $31.78 * * *$ \\
\hline No & 82.7 & 19.8 & 61.4 & 18.9 & 2141 & \\
\hline Yes & 17.3 & 14.7 & 54.8 & 30.5 & 449 & \\
\hline Chicken/Meat/Fish Daily & & & & & & $9.66^{* *} *$ \\
\hline No & 38.2 & 20.2 & 62.0 & 17.8 & 989 & \\
\hline Yes & 61.8 & 18.1 & 59.2 & 22.8 & 1601 & \\
\hline Total $^{3}$ & 100.0 & 18.9 & 60.3 & 20.9 & 2589 & \\
\hline
\end{tabular}

Note: 1. The body mass index (BMI) is the ratio of the weight in kilograms to the square of the height in metres $\left(\mathrm{kg} / \mathrm{m}^{2}\right)$.

2. Table excludes women who are pregnant and women with a birth in the preceding two months.

3. Total includes a small number of women with missing information on standard of living, education, and work participation, who are not shown separately.

4. Level of significance: ***p $\leq 0.001 ; * * \mathrm{p} \leq 0.01 ; * \mathrm{p} \leq 0.05$

Source: Computed from NFHS-2, 1998-99 data files of Kerala. 
associated. For instance, standard of living is highly associated with education (contingency coefficient of 0.40 ) and moderately with watching Television (TV) every week (contingency coefficient of 0.32). Similarly, the contingency coefficient between education and watching TV every week is 0.33 . Such association confounds the differentials observed in the bi-variate analysis. Hence, there is a need to assess the effect of an individual factor when other variables are controlled. Moreover, many of the factors associated with malnutrition are also associated with each other. So, any apparent effect of one factor on malnutrition may be due to the confounding effects of one or more of these other factors. Therefore, when assessing the effects of any one factor on malnutrition, a multivariate analysis is necessary to control for the effects of other potentially confounding factors. To this end, logistic regression analysis is carried out to quantify the net effects of these background factors on each of the dependent variables (both underweight and overweight or obese) and the results are presented in Table 6. This multivariate analysis adds to the bi-variate discussion by identifying the factors that significantly affect the likelihood of women being underweight or being overweight/obese net of all other factors.

Table 6: Results of logistic regression analysis showing the effects of selected variables on women being underweight (BMI, $<18.5 \mathrm{~kg} / \mathrm{m}^{2}$ ) and women being overweight $/$ obese $\left(\mathrm{BMI}, \geq 25.0 \mathrm{~kg} / \mathrm{m}^{2}\right.$ ) compared to normal weight (BMI, 18.5-24.9 kg/m²), Kerala, NFHS-2, 1998-99

\begin{tabular}{|c|c|c|c|c|}
\hline \multirow{2}{*}{$\begin{array}{l}\text { Characteristic } \\
\text { (1) }\end{array}$} & \multicolumn{2}{|c|}{ Values of $\beta$ coefficient } & \multicolumn{2}{|c|}{ Values of odds ratio } \\
\hline & $\begin{array}{c}\text { Overweight } \\
\text { (2) }\end{array}$ & $\begin{array}{c}\text { Underweight } \\
\text { (3) }\end{array}$ & $\begin{array}{l}\text { Overweight } \\
\text { (4) }\end{array}$ & $\begin{array}{c}\text { Underweight } \\
\text { (5) }\end{array}$ \\
\hline \multicolumn{5}{|l|}{$\overline{\text { Residence }^{(a)}}$} \\
\hline Urban & 0.090 & -0.165 & 1.094 & 0.848 \\
\hline \multicolumn{5}{|l|}{ Religion $^{(b)}$} \\
\hline Muslim & 0.710 & -0.234 & $2.034 * * *$ & 0.791 \\
\hline Christian & 0.305 & -0.341 & $1.357 *$ & 0.711 \\
\hline \multicolumn{5}{|l|}{ Caste/Tribe ${ }^{(c)}$} \\
\hline Other backward class & 0.109 & 0.120 & 1.115 & 1.128 \\
\hline Scheduled caste/tribe & -0.007 & 0.126 & 0.993 & 1.134 \\
\hline \multicolumn{5}{|l|}{ Education $^{(d)}$} \\
\hline Literate, $<$ middle school & 0.375 & -0.235 & 1.455 & 0.790 \\
\hline Middle school & 0.422 & -0.386 & 1.524 & $0.679 *$ \\
\hline High school and above & 0.393 & -0.356 & 1.482 & 0.701 \\
\hline \multicolumn{5}{|l|}{ Work Status ${ }^{(e)}$} \\
\hline Working & -0.227 & 0.092 & 0.797 & 1.096 \\
\hline \multicolumn{5}{|l|}{ Household standard of living ${ }^{(f)}$} \\
\hline Medium & 0.343 & -0.503 & 1.409 & $0.605 * * *$ \\
\hline High & 0.822 & -0.944 & $2.276 * * *$ & $0.389 * * *$ \\
\hline \multicolumn{5}{|l|}{ Current Age ${ }^{(g)}$} \\
\hline $25-34$ & 1.206 & -0.106 & $3.339 * * *$ & 0.899 \\
\hline $35-49$ & 1.688 & -0.709 & $5.409 * * *$ & $0.492 * * *$ \\
\hline \multicolumn{5}{|l|}{ Marital Status $(h)$} \\
\hline Widowed/divorced & -0.276 & 0.387 & 0.759 & $1.473 *$ \\
\hline \multicolumn{5}{|l|}{ Watches TV Every Week ${ }^{(i)}$} \\
\hline Yes & 0.353 & - & $1.434 * *$ & - \\
\hline \multicolumn{5}{|l|}{ Fruits Daily ${ }^{(j)}$} \\
\hline \multirow{2}{*}{\multicolumn{5}{|c|}{ Chicken, Meat, or Fish Daily ${ }^{(k)}$}} \\
\hline & & & & \\
\hline Yes & 0.230 & -0.021 & $1.259 *$ & 0.979 \\
\hline -2 Log Likelihood & 2213 & 2153 & & \\
\hline Chi-square & 181 & 97 & & \\
\hline d.f. & 17 & 16 & & \\
\hline Constant & -4.031 & -0.021 & & \\
\hline Total N & 2112 & 2039 & & \\
\hline
\end{tabular}

Note: Reference categories: ${ }^{(a)}$. Rural; ${ }^{\left({ }^{b}\right)}$. Hindu; ${ }^{(\mathrm{c})}$. Other caste; ${ }^{(\mathrm{d})}$. Illiterate; ${ }^{(\mathrm{e})}$. Not-working; ${ }^{(\mathrm{f})}$. Low; ${ }^{(\mathrm{g})}$. 15-24; ${ }^{(\mathrm{h})}$. Currently married; (i). No; ${ }^{(j)}$. No; ${ }^{(k)}$. No

Level of significance: $* * * \mathrm{p} \leq 0.001 ; * * \mathrm{p} \leq 0.01 ; * \mathrm{p} \leq 0.05$

'-' Variable not used in the model

Source: Computed from NFHS-2, 1998-99 data files of Kerala. 
The results of the multivariate logistic regression analysis on overweight or obese women with those of normal weight show that overweight or obesity was positively and significantly associated with religion, standard of living, age, media and food habits (Table 6). The results revealed that Muslim and Christian women were more likely (odds ratio $[\mathrm{OR}]=2.03$ and 1.36 , respectively) to be overweight or obese than the Hindu women. Women who live in households with high standard of living had a significantly higher probability of being overweight or obese. As compared with women residing in households with low standard of living, women residing in medium and high standard of living households were about 1.4 and 2.3 times more likely to be overweight or obese, respectively. The risk of being overweight or obese increases rapidly with age, older women displayed a higher probability of being overweight or obese compared to younger women. Women in the age group 25-34 and 3549 were 3.3 and 5.4 times more likely to be overweigh or obese as compared with women in youngest age group (15-19). Watching television every week had a significant positive effect (OR $=1.43$ ) on the risk of being overweight or obese. For the diet/nutrition variables, women who reported eating fruits daily $(\mathrm{OR}=1.55)$ and women who consume chicken, meat or fish $(\mathrm{OR}=1.26)$ were more likely to be overweight or obese than those who ate them occasionally or rarely. Among the other variables, residence, caste, education, work status and marital status of women did not pose significant effect on women's overweight and/or obese status.

The results of the logistic regression model comparing underweight women with those of normal weight are similar to those shown for the model of overweight or obese, but in the opposite direction. In this model also, standard of living, age and marital status of women are found to be significant risk factors of chronic energy deficiency in women (Table 6). Conversely, a woman's residence, religion, caste, work status and media/ dietary variables are not significant on women's nutritional status. The results indicates that women living in poorer households were much more likely to be underweight than those living in households with higher socioeconomic status. As compared with women residing in poorer households/low standard of living, women who lived in households with a high standard of living $(\mathrm{OR}=0.39)$ and with a medium standard of living $(\mathrm{OR}=0.61)$ have significantly lower probability of being underweight. Women with middle school level of education and older women were at a significantly lower risk $(\mathrm{OR}=0.68$ and 0.49 , respectively) of CED malnutrition compared to their counterparts. Never married women were 1.5 times more likely to be undernourished than the currently married women.

\section{CONCLUSIONS}

The South Indian state of Kerala has made significant advances in demographic, epidemiological and health care transitions. On the other hand, the state is also under-going rapid nutrition transition-considerable proportions of women were underweight and overweight or obese, with only slightly greater preponderance of the latter. The proportion of under/over weight women in the state was consistent with the nutrition transition and thus, the state is undergoing rapid transition. This paper therefore, consequently examined the trends and determinants of the coexistence of underweight and overweight or obesity among women of age 1549 years using the data from National Nutrition Monitoring Bureau (NNMB) and the second National Family Health Survey (NFHS-2). Results based on the time-trend analysis from the NNMB data show a decreasing trend in the prevalence of chronic energy deficiency and an increasing trend in the proportions of overweight or obese. The trends in the intake of both energy and proteins also reflect almost steady increase over the last two decades in the rural areas, however, below the recommended dietary allowances.

Findings from the multivariate analysis on NFHS-2 data suggest that broadly similar set of factors is relevant to both under-and-overweight malnutrition. For example, standard of living and age are positively and significantly associated with overweight or obesity and inversely related to under-nutrition, that is, women in the highest socioeconomic group and women in the middle and older age groups are more likely to be overweight or obese and less likely to be underweight. Further, it has been observed that Muslim and Christian women are more likely to be overweight or obese than the Hindu women. This is likely related to differences in diet, physical activity and socioeconomic status. Further examination of NFHS-2 data show that Muslims and Christians were more likely to be found in the 
higher socioeconomic groups (30 per cent of Muslims and 40 per cent of Christians in the high standard of living group compared with 26 per cent among Hindus); lower rates of participation in the workforce (91 per cent of Muslims and 74 per cent of Christians reported not working compared with 69 per cent in the Hindus), a greater likelihood of consuming chicken or meat or fish daily (73 per cent of Muslims and 65 per cent of Christians compared with 54 per cent in the Hindu). Therefore, it is possible that Muslim and Christian women have lifestyles that increase their susceptibility to becoming overweight or obese. Among other variables, women who watch television more than once a week and women who reported eating fruits daily and consume chicken or meat or fish are more likely to be overweight or obese than their counterparts. The risk of CED or underweight is significantly higher among never married women and lower among literate women. These results are fairly consistent findings in many other developing countries (including India), which are in the early stage of nutrition transition (Singh et al. 1999; Griffiths and Bentley 2001; Shukla et al. 2002; Monteiro et al. 2004). On the other hand, though the results from the bi-variate analysis show the proportion of the overweight in the urban areas ( 25 per cent) is more in comparison to the rural areas (19 per cent), the logistic regression analysis reveals that the place of residence is not a significant determinant in deciding the overweight, and the differences between rural and urban areas were removed, when controlled for socioeconomic and other variables. Thus, socioeconomic status, not rural-urban residence, was the most important predictor of women's nutritional status in Kerala. This finding is also consistent with Popkin's perspective that urban residence per se is not the cause of overweight rather; differences in lifestyle factors that predict over-weight and obesity are associated with living in an urban environment (Popkin 1998). A similar study conducted with the data in the state of Andhra Pradesh also reveals the same tendency (Griffiths and Bentley 2001).

It has been identified that different ethnic groups have different amount of fat content and among Asian population, abdominal or central obesity is more common than obesity defined by BMI (Mc Keigue et al. 1991) and health risks associated with overweight and obesity occur at lower levels of BMI than in North America or Europe (Dudeja et al. 2001). In a study Gopalan
(1998) also observed that about 20 per cent of adults who were not overweight or obese as per the BMI definition still had abdominal obesity. In this situation, a WHO expert consultation in July 2002 has proposed a BMI lower limit of 23 for overweight among Asians, instead of the $25 \mathrm{~kg} /$ $\mathrm{m}^{2}$ used now (Choo 2002). If 23 had been used as the lower cutoff point for overweight women, the gravity overweight situation in the country and in the State of Kerala would worsen and the proportion of women classified as overweight or obese would increase from 11 per cent to 19 per cent in India as a whole, and from 22 per cent to 36 per cent for Kerala (Table 1). The percentage of overweight and obese women in Kerala would also rise from 33 per cent to 51 per cent among women living in households with a high standard of living; from 26 per cent to 51 per cent among Christian women and older women and from 25 per cent to 39 per cent among Muslim women.

In sum, this study has shown that both chronic underweight and overweight are equally present in Kerala, with important public health implications for the burden of diseases associated with both extremes of physical status. The substantial proportion of underweight persons, together with continuing high overall levels of overweight or obese persons, produces a dual burden of nutritional disorders for the state. The overweight and obesity makes people prone to noncommunicable and degenerative diseases, whereas, under-nutrition may make them prone to communicable diseases and reduce productivity. Therefore, the existence of a double burden poses a big challenge. What are the policy implications of these findings? Although the factors associated with underweight, obesity and overweight are very similar, the challenges and solutions required to tackle the extremes of both over-and-underweight in the upper and lower socioeconomic groups are not. Moreover, as these may be coexisting, not only at state level but also even at household level, no uniform intervention strategy can be advocated. Therefore, to reduce the both forms of malnutrition, effective policies and information and health education programs for women are urgently required to ensure adequate access to health services and to understand the components of a healthy diet.

\section{ACKNOWLEDGEMENTS}

We would like to thank the Institute for 
Population Sciences (IIPS), Mumbai, India and MEASURE DHS+, ORC MACRO, USA for providing the second National Family Health Survey data for the state of Kerala. We are also grateful to Professor Arup Maharatna, Dr. S. Mulay, Dr. R. Nagarajan and Mr. P. Phanivas for their kind support and constant encouragement at various levels.

\section{REFERENCES}

Central Statistical Organisation 1999. Selected SocioEconomic Statistics, India 1998. New Delhi: Department of Statistics and Programme Implementation, Government of India.

Choo Vivien 2002. WHO Reassesses appropriate body mass index for Asian populations. Lancet, 360: 235.

Cole T J, Bellizzi M C, Flegal K M, Dietz WH 2000. Establishing a standard definition for child overweight and obesity worldwide: International survey. Br Med J, 320: 1-6.

Dudeja V, Mishra A, Pandey R.M 2001. BMI does not accurately predict overweight in Asian Indians in Northern India. British Journal of Nutrition, 86:10512.

Gopalan C 1998. Obesity in the Indian urban 'middle class'. Bulletin of Nutrition Foundation of India, 19: 1-5.

Griffiths PL, Bentley ME 2001. The nutrition transition is underway in India. Journal of Nutrition, 131(10): 2692-2700.

Indian Council of Medical Research (ICMR) 1990. Recommended Dietary Allowances for Indians. A Report of Expert Group of ICMR, New Delhi.

India, Registrar General 2004. Sample Registration System Bulletin. New Delhi: Vital Statistics Division, Ministry of Home Affairs.

India, Registrar General 2004. Census of India 2001, India. Primary Census Abstract-Total population, Table A-5, Series-1. New Delhi: Controller of Publications.

National Family Health Survey and Fact Sheet 2006. From <http://www.nfhsindia.org/factsheet.html> (Retrieved November 19, 2006)

International Institute for Population Sciences (IIPS), ORC Macro 2000. National Family Health Survey (NFHS-2), 1998-99: India, Mumbai: IIPS.

International Institute for Population Sciences (IIPS), ORC Macro 2001. National Family Health Survey (NFHS-2), 1998-99: Kerala, Mumbai: IIPS

Mc Keigue PM, Shah B, Marmot MG 1991. Relation of central obesity and insulin resistance with high diabetes prevalence and cardiovascular risk in South Asians. Lancet, 337: 382-386.

Mendez MA Monteiro CA, Popkin BM 2005. Overweight exceeds underweight among women in most developing countries. American Journal of Clinical Nutrition, 81(3): 714-21.

Merchant KM, Kurtz KM 1993.Women's Nutrition through the Life Cycle: Social and Biological Vulnerabilities. In: MA Koblinsky, J Timyan, J Gay (Eds.): The Health of Women: A Global Perspective. Boulder, CO: West View Press, pp.63-90.
Monteiro CA, Conde WL, Popkin BM 2004. The burden of disease from undernutrition and overnutrition in countries undergoing rapid nutrition transition: A view from Brazil. American Journal of Public Health, 94: 433-434.

National Institute of Nutrition 1991. Body Mass Index and Mortality Rates: A Ten Year Retrospective Study, Annual Report, 1989-90. Hyderabad: National Institute of Nutrition.

National Nutrition Monitoring Bureau 1991. Report of NNMB Repeat Surveys (1988-90). Hyderabad: National Institute of Nutrition.

National Nutrition Monitoring Bureau 1993. Report of NNMB Repeat Surveys (1991-92). Hyderabad: National Institute of Nutrition.

National Nutrition Monitoring Bureau 1999. Report of Second Repeat Survey, Rural. NNMB Technical Report No. 18, Hyderabad: National Institute of Nutrition.

National Nutrition Monitoring Bureau 2002. Diet and Nutritional Status of Rural Population. NNMB Technical Report No. 21. Hyderabad: National Institute of Nutrition.

Panikar PGK 1999. Health Transition in Kerala. Kerala Research Programme on Local Level Development. Discussion Paper No. 10. Thiruvananthapuram: Centre for Development Studies.

Panikar PGK, Soman CR 1981. Health Status of Kerala: Paradox of Economic Backwardness and Health Development. Thiruvananthapuram: Centre for Development Studies.

Popkin BM 1998. Population and Development Overview: The Nutrition Transition. In: The Encyclopedia of Human Nutrition. London, UK: Academic Press, pp. 1562-1573

Popkin BM, Horton SH, Kim S 2001. The nutrition transition and prevention of diet-related diseases in Asia and the Pacific. Food Nutrition Bulletin, 22 (Supplement 1): 58

Ramesh P 2006. Malnutrition among Women in Kerala: An Analysis of Trends, Differentials and Determinants. Working Paper No.7, Pune: Gokhale Institute of Politics and Economics.

Roy TK, Sumati Kulkarni, Vaidehi Y 2004. Social inequalities in health and nutrition in selected States. Economic and Political Weekly, 34(7): 677-683.

Shetty PS 2002. Nutrition transition in India. Public Health Nutrition, 5(1A): 175-182.

Shukla HC, Gupta PC, Mehta HC, Hebert JR 2002. Descriptive epidemiology of body mass index of an urban adult population in Western India. Journal of Epidemiology Community Health, 56: 876-880.

Singh RB, Beegom R, Mehta AS 1999. Social class, coronary risk factors and under-nutrition, a double burden of diseases, in women during transition, in five Indian cities. International Journal of Cardiology, 69: 139-147.

Tinker A, Daly P, Green C, Saxenian H, Lakshmi narayanan R, Gill K 1995. Women's Health and Nutrition. World Bank Discussion Paper No. 256. Washington DC: World Bank.

World Health Organization (WHO) 1995. Physical Status: The Use and Interpretation of Anthropometry, Report of a WHO Expert Committee. Technical Report Series No. 854. Geneva: WHO. 